Ekonomia - Wroclaw Economic Review 23/3 (2017)

Acta Universitatis Wratislaviensis

No 3807

DOI: 10.19195/2084-4093.23.3.3

\author{
Marek Szczepański \\ Politechnika Poznańska \\ Wydział Inżynierii Zarządzania \\ Katedra Nauk Ekonomicznych \\ marek.szczepanski@put.poznan.pl
}

\title{
Quasi-obowiązkowe uczestnictwo w pracowniczych programach emerytalnych na przykładzie Wielkiej Brytanii. Szanse i zagrożenia
}

\begin{abstract}
Artykuł nadesłany: 15 marca 2017 r.; artykuł zaakceptowany: 31 stycznia 2017 r.
\end{abstract}
JEL Classification: J18, J32

Keywords: employee (occupational) pension schemes, volunteering, mandatory and quasi-compulsory participation, economic and legal-institutional consequences

Abstract

Quasi-compulsory participation in occupational pension schemes on example of Great Britain: opportunities and threats

The purpose of this article is to identify the opportunities and threats associated with compulsory or quasi-compulsory participation in occupational pension schemes based on the literature review of the subject and the comparative studies of the effects of introducing such solutions in selected countries (UK, Ireland). On this basis, conclusions and recommendations will be made regarding the proposed introduction of similar solutions in the Polish pension system.

\section{Wstęp}

Celem artykułu jest identyfikacja szans i zagrożeń związanych z obowiązkowym lub quasi-obowiązkowym uczestnictwem w pracowniczych programach emerytalnych na podstawie badań porównawczych efektów wprowadzenia tego typu rozwiązań w wybranych państwach. Autor zamierza udzielić odpowiedzi na następujące pytania (rozwiązać problemy) badawcze: 
1. Czy wprowadzenie obowiązkowego zapisu pracowników do pracowniczego (zakładowego) systemu emerytalnego (ang. auto-enrolment) z opcją odstąpienia (opt-out option) w Wielkiej Brytanii przyczyniło się do generowania dodatkowych oszczędności emerytalnych?

2. Czy rzeczywiste zachowania i decyzje uczestników pracowniczych programów emerytalnych włączonych do programu w formie automatycznego (domyślnego) zapisu potwierdzają założenia ekonomii behawioralnej w odniesieniu do podejmowania decyzji emerytalnych?

3. Czy jest to rozwiązanie zwiększające poziom zabezpieczenia emerytalnego także grup zawodowych o niskich i średnich dochodach, do których przede wszystkim powinny być adresowane dodatkowe systemy emerytalne — zarówno zakładowe, jak i indywidualne?

4. Jakie zagrożenia (z punktu widzenia pracodawców i ich interesów oraz finansów publicznych) ujawniły się do tej pory w trakcie wdrażania rozwiązań instytucjonalnych polegających na automatycznym zapisywaniu nowo przyjętych pracowników do pracowniczego programu emerytalnego?

5. Jakie wnioski z doświadczeń brytyjskich można wyciągnąć dla Polski wobec pojawiających się propozycji wprowadzenia obowiązkowego lub quasi-obowiązkowego uczestnictwa w pracowniczych programach emerytalnych w naszym kraju?

Zakres przedmiotowy badań obejmuje system automatycznego zapisu do pracowniczych programów emerytalnych w Wielkiej Brytanii w latach 2012-2016 oraz projekcje dotyczące poziomu uczestnictwa oraz aktywów, które zostaną zgromadzone w tym programie do roku 2018.

W artykule przeprowadzono weryfikację hipotezy badawczej, zakładającej, że w przypadku quasi-obowiązkowego uczestnictwa w pracowniczych programach emerytalnych z opcją odstąpienia (opt-out option) grupami pracowniczymi najbardziej narażonymi na wycofywanie oszczędności z zakładowego systemu emerytalnego są osoby o najniższych dochodach i niższym poziomie wykształcenia. Uzasadniono także tezę o wiodącej roli pracodawcy w pracowniczym programie emerytalnym oraz potrzebie skorelowania rozwiązań prawno-instytucjonalnych i zachęt ekonomiczno-fiskalnych mających na celu zwiększenie poziomu uczestnictwa w pracowniczych programach emerytalnych, podwyższenie poziomu zabezpieczenia emerytalnego oraz wzrost stopy oszczędności w gospodarce z interesami pracodawców i realizowaną przez nich strategią zarządzania zasobami ludzkimi.

\section{Teoretyczne podstawy badań porównawczych pracowniczych programów emerytalnych}

Badania komparatystyczne systemów emerytalnych napotykają na podstawową trudność, jaką jest duża zmienność przedmiotu badań — dostępność danych statystycznych, ich międzynarodowa porównywalność (Chybalski 2016, s. 10). 
Systemy emerytalne stale ewoluują, a zmiany reformy emerytalnej wprowadzone w większości państw rozwiniętych gospodarczo na przełomie XX i XXI wieku w odpowiedzi na wyzwania związane z demograficznym starzeniem się społeczeństwa i przekształcenia rynku pracy są kontynuowane. Jeszcze większym wyzwaniem są badania porównawcze pracowniczych programów emerytalnych ${ }^{1}$, zwanych również zakładowymi systemami lub planami emerytalnymi (ang. occupational pension plans, occupational pension schemes, workplace pensions). Cechą charakterystyczną pracowniczych programów emerytalnych jest ich związek z zakładem pracy lub stosunkiem pracy. Mogą być prowadzone w jednym zakładzie pracy, grupie przedsiębiorstw lub powiązanych z sobą instytucji, a nawet w skali całej branży (często wymóg ich utworzenia zawarty jest w zbiorowych układach pracy).

Trudności powiązane z prowadzeniem rzetelnych badań porównawczych PPE to nie tylko efekt mniejszej dostępności czy też niekompletności danych na temat programów zakładowych w porównaniu do systematycznie publikowanych statystyk o publicznych systemach zabezpieczenia emerytalnego (np. OECD 2015; OECD 2016). Spore zamieszanie wywołuje również klasyfikacja systemów zakładowych. W typologii systemów emerytalnych stosowanej przez organizacje międzynarodowe (OECD 2005, s. 11) pracownicze programy emerytalne zaliczane są do prywatnych systemów emerytalnych (ang. private pension plans). W klasycznym, trójwarstwowym (trójfilarowym) podziale systemów zabezpieczenia emerytalnego stosuje się kryterium podmiotowe. Poszczególne warstwy (filary) tworzone są z inicjatywy innych podmiotów:

1. publiczny — kreowany z inicjatywy państwa;

2. zakładowy - pracodawców;

3. indywidualny - gospodarstwa domowego emeryta.

W tym ujęciu PPE najczęściej zalicza się do drugiej warstwy (II filaru) systemu emerytalnego, aczkolwiek w niektórych krajach, gdzie mają charakter dobrowolny (jak do tej pory w Polsce), sytuowane są w obrębie III filaru jako dodatkowe, dobrowolne systemy emerytalne.

Różnice terminologiczne i wielość stosowanych kryteriów klasyfikacji części składowych systemów emerytalnych utrudniają porównania międzynarodowe. Statystyki prowadzone w poszczególnych krajach, opierające się na odmiennych kryteriach klasyfikacyjnych, często przedstawiają diametralnie różny obraz zakładowych systemów emerytalnych — poziomu uczestnictwa, zgromadzonych w nich aktywów czy też roli, jaką faktycznie odgrywają w systemach zabezpieczenia emerytalnego poszczególnych państw. Ponieważ gromadzone w nich oszczędności zwykle kwalifikowane są jako zasoby prywatne i inwestowane na rynku kapitałowym, a nie jako środki w publicznym systemie zabezpieczenia emerytalnego,

${ }^{1}$ Dla oszczędności miejsca w niniejszym artykule zamiennie używane będzie pełne określenie: ,pracowniczy program emerytalny” i skrót PPE. 
w niektórych opracowaniach do aktywów zakładowych syste-mów emerytalnych mylnie zaliczano środki odprowadzane do kapitałowych segmentów w systemach zabezpieczenia emerytalnego. Dotyczy to oczywiście państw, które w ramach reform emerytalnych, mających miejsce na przełomie XX i XXI wieku, wprowadziły wielofilarowe (wielowarstwowe) publiczne sys-temy emerytalne - z segmentem finansowanym kapitałowo (inwestowanie składek emerytalnych na rynku finansowym) obok segmentu repartycyjnego (finansowanie wypłaty bieżących składek emerytalnych z bieżących składek lub podatków). Zdarzało się także (zob. Oxera 2013, s. 21), że PPE traktowano jako system bazowy finansowany przez pracodawcę, a otwarte fundusze emerytalne (OFE), stanowiące część publicznego systemu emerytalnego i obligatoryjnie współfinansowane przez pracodawcę, zaliczano do indywidualnych oszczędności emerytalnych, na równi z dobrowolnymi oszczędnościami na indywidualnych kontach emerytalnych (IKE) czy indywidualnych kontach zabezpieczenia emerytalnego (IKZE), finansowanych z indywidualnych oszczędności pracowników. W takim ujęciu można by wręcz odnieść wrażenie, że PPE stanowią bazową część całego systemu emerytalnego w Polsce, podczas gdy do tej pory obejmują one zaledwie około 2,6\% ogółu zatrudnionych.

Jest to zresztą szerszy problem, nie tylko natury klasyfikacyjno-porządkowej czy statystycznej. Chodzi o odpowiedź na kluczowe pytanie o rolę zakładowego systemu emerytalnego w całym systemie zabezpieczenia emerytalnego. Czy są to dodatkowe, prywatne oszczędności (tyle że zbierane i inwestowane w formie grupowej, w zakładzie pracy), czy też stanowić powinny immanentną część systemu zabezpieczenia emerytalnego? Autor niniejszego artykułu jest zwolennikiem tego drugiego ujęcia. Jest to zgodne $\mathrm{z}$ - dominującym przynajmniej od lat dziewięćdziesiątych XX wieku w ekonomii emerytalnej i teorii polityki społecznej — paradygmatem, zgodnie z którym system emerytalny nie ogranicza się do publicznego (pod)systemu, lecz składa się z kilku warstw (filarów), z których zbudowany jest system zabezpieczenia finansowych dochodów „na starość”, po zakończeniu aktywności zawodowej.

Na dochody emerytów mogą się składać środki pieniężne pochodzące z różnych źródeł. Uwzględnia to w swojej definicji Maciej Żukowski, który pod pojęciem zabezpieczenia emerytalnego rozumie „ogół zinstytucjonalizowanych źródeł zabezpieczenia dochodów pieniężnych na okres starości" (Żukowski 1997, s. 17). Tak więc PPE powinny być badane w szerszym kontekście, w ramach międzynarodowych porównań całych systemów zabezpieczenia społecznego. Oczywiście nie wyklucza to możliwości analitycznego podejścia i badań wyodrębnionych aspektów ich funkcjonowania (np. wyników inwestycyjnych funduszy emerytalnych, w które inwestowane są środki gromadzone w PPE, kosztów obsługi programu, opłacanych na rzecz dostawców usług finansowych dla programu - providerów). 


\section{Metodyczne założenia i przesłanki badań porównawczych PPE}

Związek podmiotowy pracowniczego programu emerytalnego z zakładem pracy lub stosunkiem zatrudnienia i szczególna rola pracodawcy w tworzeniu i prowadzeniu programu zakładowego pociąga za sobą istotne konsekwencje natury teoretycznej i metodologicznej. Prowadząc badania porównawcze pracowniczych programów emerytalnych, trzeba brać pod uwagę co najmniej cztery perspektywy poznawcze:

1. ujęcie makro - jaką rolę pełnią PPE w całym systemie zabezpieczenia społecznego danego kraju, jaki jest poziom jego upowszechnienia (jaką część populacji osób zatrudnionych obejmują systemy zakładowe);

2. ujęcie mikro - perspektywa pracownika, uczestnika programu zakładowego; poszukiwanie odpowiedzi na pytanie, w jakim stopniu stanowią one instrument alokacji dochodu w cyklu życia (wygładzania konsumpcji — ang. consumption smoothing) dla pracownika-uczestnika programu; $w$ jakim zakresie ograniczają ryzyko emerytalne - pierwsza faza ryzyka związana z dożyciem do ustawowego wieku emerytalnego i potrzebą skompensowania ubytku dochodu po zakończeniu aktywności zawodowej, druga faza - indywidualne ryzyko długowieczności u osób żyjących dłużej niż przeciętnie dla danego rocznika emerytów, polegające na możliwości wyczerpania dodatkowych zasobów emerytalnych zgromadzonych na starość (por. Szumlicz 2005; Blake 2006);

3. ujęcie uwzględniające interes pracodawcy - na ile za pomocą progra$\mathrm{mu}$ zakładowego ( $\mathrm{w}$ ramach określonych regulacji prawno-instytucjonalnych i stosowanych $\mathrm{w}$ danym państwie systemów zachęt fiskalnych kierowanych do sponsorów i uczestników pracowniczego programu emerytalnego) pozwalają one pracodawcom realizować określone cele związane z polityką kadrową (klasyczna funkcja programów zakładowych — budowanie lojalności pracowników, związanie ich z zakładem pracy) czy też wizerunkową (np. program emerytalny jako element strategii społecznej odpowiedzialności biznesu);

4. ujęcie finansowo-produktowe - z uwzględnieniem aspektu zarządzania ryzykiem (ocena efektywności inwestycyjnej zadań realizowanych przez dostawców usług finansowych - ang. providers) dla zakładowych systemów emerytalnych czy też badania porównawcze poszczególnych produktów emerytalnych o charakterze inwestycyjnym bądź ubezpieczeniowym (w aspekcie kosztowym, z punktu widzenia podziału ryzyka inwestycyjnego między pracodawcę i pracownika itp.).

W niniejszym opracowaniu zostaną przedstawione wyniki badań porównawczych tych PPE, w których wykorzystano zasadę automatycznego zapisu do programu nowo przyjętego pracownika z możliwością odstąpienia w określonym czasie (auto-enrolment with opt-out option). Badania przeprowadzono w skali makro, bez szczegółowych analiz produktowych. Są już bowiem dostępne mię- 
dzynarodowe badania porównawcze produktów emerytalnych, również w systemach zakładowych, z uwzględnieniem wyników inwestycyjnych i kosztów obsługi (Better Finance 2016).

W artykule wykorzystano teoretyczne założenia analiz systemów emerytalnych, wypracowane na gruncie ekonomii emerytalnej (Blake 2006; Barr, Diamond 2010; Chybalski 2016), klasyfikację dodatkowych systemów emerytalnych proponowaną przez organizacje międzynarodowe (World Bank 1994; World Bank 2005; OECD 2005), a także wyniki badań uwarunkowań rozwojowych zakładowych systemów emerytalnych w Polsce (Szczepański 2010) oraz badań porównawczych pracowniczych programów emerytalnych w krajach Unii Europejskiej (Petelczyc 2016). Nawiązano również do wybranych koncepcji ekonomii behawioralnej.

\section{Auto-enrolment w pracowniczych programach emerytalnych w Wielkiej Brytanii — założenia programu i dotychczasowe efekty}

Wielka Brytania należy do państw, w których podstawowe zabezpieczenie emerytalne oferowane przez publiczny system emerytalny jest relatywnie niskie, finansowane na zasadzie zaopatrzeniowej (z ogólnych podatków, a nie składek ubezpieczeniowych). Dodatkowe systemy emerytalne — zakładowe i indywidualne - w różnych konfiguracjach, organizowane w większości przez instytucje prywatne, od dawna stanowiły dla osób pracujących istotny składnik zabezpieczenia finansowego na starość. Na przykład według międzynarodowych analiz porównawczych firmy Towers Watson z 2013 roku udział aktywów zgromadzonych w PPE (zaliczanych do II filaru) w całości aktywów emerytalnych, z których już korzystają emeryci, wynosił aż 88\% (Amzallag, Kapp \& Kok 2014, s. 11). Również pod względem wartości aktywów finansowych zgromadzonych w zakładowych systemach emerytalnych PPE w Wielkiej Brytanii sytuują się w europejskiej czołówce, obok takich państw, jak Holandia, Finlandia czy Dania (Amzallag, Kapp \& Kok 2014, s. 13). W 2012 roku wartość aktywów PPE w relacji do PKB wynosiła około 70\%; dla porównania w Holandii było aż 140\% PKB (są to jednak dane z 2012 roku), a w Polsce - zaledwie 6\%o PKB. Nie oznacza to jednak, że wszyscy czy też większość pracowników w Wielkiej Brytanii jest objęta zakładowym zabezpieczeniem emerytalnym. W przeciwieństwie do takich państw, jak Holandia, Szwecja, Finlandia czy Szwajcaria, gdzie uczestnictwo w PPE ma charakter powszechny (na zasadzie obowiązkowej lub quasi-obowiązkowej), poziom uczestnictwa w zakładowych systemach emerytalnych w Zjednoczonym Królestwie według danych OECD wynosił w 2013 roku zaledwie 30\% (OECD 2015, s. 189). Z kolei brytyjskie źródła podają, że w 2012 roku 
w pracowniczych programach emerytalnych dodatkowo oszczędzało na emeryturę w zakładzie pracy około 55\% ogółu uprawnionych pracowników (Department for Work and Pensions 2015, s. 5). Widoczne duże rozbieżności mogą wynikać ze wspomnianych różnic klasyfikacyjnych, jak i trudniejszego dostępu do danych o zakładowym zabezpieczeniu emerytalnym w poszczególnych krajach w porównaniu do statystyk publicznych systemów emerytalnych.

Międzynarodowe statystyki nie podają, jaką część aktywów PPE stanowią wpłaty od osób o wyższych dochodach. Można jednak przypuszczać, że - podobnie jak w innych krajach — w dodatkowych systemach emerytalnych chętniej oszczędzają osoby o wyższych dochodach nominalnych i wyższym dochodzie dyspozycyjnym, a najtrudniej zmobilizować do tego pracowników o najniższych dochodach (pierwsze dwa decyle w rozkładzie dochodowym danej populacji). Prawidłowość ta dotyczy oczywiście państw, w których gromadzenie dodatkowych oszczędności emerytalnych w PPE ma charakter dobrowolny. Hipoteza wymaga jednak weryfikacji na podstawie krajowych, bardziej szczegółowych analiz PPE.

$\mathrm{W}$ celu upowszechnienia poziomu uczestnictwa w zakładowych systemach emerytalnych, zwiększenia stopy zastąpienia dochodów emerytalnych w relacji do zarobków z okresu aktywności zawodowej oraz docelowo zmniejszenia zależności od publicznego systemu emerytalnego, który zapewnia tylko podstawowe zabezpieczenie finansowe na starość (ochronę przed ubóstwem), w Wielkiej Brytanii od 2012 roku sukcesywnie wprowadzany jest system zakładowego zabezpieczenia emerytalnego o charakterze quasi-obowiązkowym, oparty na automatycznym zapisie nowo zatrudnianych pracowników. Zreformowany system zakładowego zabezpieczenia emerytalnego nosi nazwę automatic enrolment (lub skrótowo auto-enrolment). Zobowiązuje on pracodawców do włączenia do kwalifikowanego pracowniczego programu emerytalnego wszystkich pracowników, którzy spełniają określone kryteria wieku (co najmniej 22 lata) i dochodu (co najmniej 10 tysięcy GBP rocznie), pracują wyłącznie lub głównie w Wielkiej Brytanii i opłacają przynajmniej minimalną składkę (Departament for Work and Pensions 2016, s. 1). Pracownicy o niższych dochodach też mają prawo przyłączyć się do PPE, ale na zasadzie dobrowolności. Włączeni do pracowniczego programu emerytalnego pracownicy mają możliwość odstąpienia (opt-out option). Po trzech latach pracodawca ma jednak obowiązek ponownie włączyć ich do zakładowego programu emerytalnego, chyba że pracownik raz jeszcze zgłosi wolę odstąpienia. Wyjście z programu w ciągu miesiąca upoważnia do odzyskania wpłaconej przez pracownika składki (ale bez składki pracodawcy i ulgi podatkowej), natomiast wybór opt-out późniejszym terminie powoduje, że wcześniej wpłacone składki pozostaną $\mathrm{w}$ programie emerytalnym do osiągnięcia przez pracownika wieku emerytalnego. Zapobiega to nadmiernej fluktuacji środków gromadzonych w PPE i umożliwia dostawcom usług finansowych (providerom) obsługującym zakładowy system emerytalny efektywne inwestowanie środków. Większość jednak pozostaje i nadal oszczędza na emeryturę w zakładzie pracy. 
Początkowo auto-enrolment objął tylko dużych pracodawców, następnie średnich, a docelowo - do 2018 roku wszyscy pracodawcy (w dużych, średnich i małych przedsiębiorstwach oraz innych zakładach pracy) będą zobowiązani do włączenia swoich pracowników do pracowniczego programu emerytalnego, opłacania za nich wymaganej składki i odprowadzania składek opłacanych przez pracowników.

Wysokość minimalnej składki opłacanej do programu przez pracownika, pracodawcę oraz ulg podatkowych wspierających oszczędzanie na emeryturę w zakładzie pracy przedstawia tabela 1 .

Tabela 1. Wysokość składek wnoszonych przez pracodawców i pracowników oraz ulg podatkowych w zakładowych systemach emerytalnych z automatycznym zapisem w Wielkiej Brytanii w latach 2012-2019

\begin{tabular}{c|c|c|c|c}
\hline Okres & $\begin{array}{c}\text { Minimalna } \\
\text { składka } \\
\text { opłacana przez } \\
\text { pracownika* }\end{array}$ & $\begin{array}{c}\text { Ulga } \\
\text { podatkowa }\end{array}$ & $\begin{array}{c}\text { Minimalna } \\
\text { składka } \\
\text { opłacana przez } \\
\text { pracodawcę** }\end{array}$ & $\begin{array}{c}\text { Minimalna składka } \\
\text { łączna (pracodawca } \\
\text { +pracownik)** }\end{array}$ \\
\hline $1.01 .2012-4.04 .2018$ & $0,8 \%$ & $0,2 \%$ & $1,0 \%$ & $2,0 \%$ \\
\hline $6.04 .2018-5.04 .2019$ & $2,4 \%$ & $0,6 \%$ & $2,0 \%$ & $5,0 \%$ \\
\hline od 6.04 .2019 & $4,0 \%$ & $1,0 \%$ & $3,0 \%$ & $8,0 \%$ \\
\hline
\end{tabular}

* dotyczy pracowników otrzymujących tak zwany minimalny dochód kwalifikowany w wysokości co najmniej 10 tys. GBP rocznie

** rzeczywista wysokość składki opłacanej przez pracownika zależnie od rodzaju prowadzonego programu emerytalnego $\mathrm{z}$ automatycznym zapisem

Źródło: The Pensions Regulator, www.thepensionsregulator.gov.uk (dostęp: 15.01.2018).

Zastąpienie dobrowolności uczestnictwa w zakładowym systemie emerytalnym udziałem o charakterze quasi-obowiązkowym (automatyczny zapis uprawnionych pracowników z opcją odstąpienia) budziło i nadal budzi sporo kontrowersji (Spencer 2015, s.1), choćby dlatego, że ogranicza swobodę wyboru po stronie pracownika (możliwość wyjścia jest ograniczona tylko do kilku tygodni, bodźcem negatywnym jest ponadto utrata ulg podatkowych dla uczestnika programu oraz składki opłacanej przez pracodawcę), a dla pracodawcy oznacza dodatkowy obowiązek i zwiększa koszt pracy. Wielu interesariuszy (reprezentanci pracodawców, niektórzy politycy) wyrażało opinie, że nie odpowiada to liberalnej doktrynie polityki społecznej przyjętej w krajach anglosaskich, zgodnie z którą każdy obywatel powinien sam dbać o swoją zamożność i dodatkowe zabezpieczenie na starość, a państwo co najwyżej powinno mu to umożliwić. Mimo to reforma emerytalna wprowadzająca automatic enrolment jest konsekwentnie realizowana i przynosi już wymierne, pozytywne rezultaty.

Według danych na koniec marca 2015 roku od rozpoczęcia reformy w 2012 roku do pracowniczych programów emerytalnych zostało automatycznie włączonych 5,2 mln nowych pracowników. Dzięki temu udało się powstrzymać spadek (w sektorze prywatnym) i spowodować znaczący wzrost uczestnictwa 
w zakładowym zabezpieczeniu emerytalnym do poziomu 75\% uczestników (łącznie - w sektorze publicznym i prywatnym) — dla porównania w 2012 roku było to 55\% uczestników PPE. Na podkreślenie zasługuje skokowy wzrost liczby pracowników oszczędzających na emeryturę $\mathrm{w}$ zakładzie pracy, zatrudnionych u prywatnych pracodawców (z 42\% w 2012 roku do 70\% w 2015 roku). Mniejszy w punktach procentowych był wzrost uczestnictwa w PPE w sektorze publicznym (z 88\% w 2012 roku do 91\% w 2015 roku), gdzie już wcześniej partycypacja w zakładowym zabezpieczeniu emerytalnym (zaliczanym w Wielkiej Brytanii do drugiej warstwy systemu emerytalnego) była bardzo wysoka. To oznacza, że oszczędzanie w zakładowym systemie emerytalnym stało się normą dla większości pracowników w Wielkiej Brytanii (The Pensions Regulator 2016, s. 3).

Według stanu na koniec marca 2015 roku $^{2}$ pracodawcy zobowiązani do utworzenia dla swoich pracowników programu emerytalnego z automatycznym zapisem zatrudniali około $22 \mathrm{mln}$ pracowników, co stanowiło mniej więcej jedną trzecią siły roboczej — ponad $40 \%$ ogółu zatrudnionych to osoby już wcześniej uczestniczące w zakładowych systemach emerytalnych, a niewielki odsetek - uczestnicy programów zakładowych w formule zdefiniowanego świadczenia (DB) lub hybrydowej (łączących elementy zdefiniowanego świadczenia - DB i zdefiniowanej składki - DC, które ulegną przekształceniu w programu o zdefiniowanej składce) (The Pensions Regulator 2016, s. 25). Udział poszczególnych grup w rynku pracy ilustruje rysunek 1 .
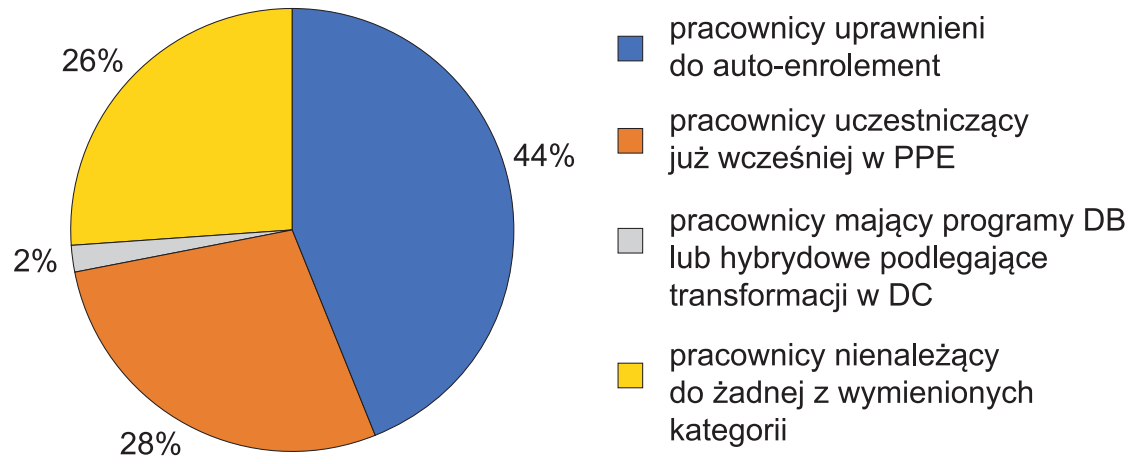

Rysunek 1. Udział poszczególnych grup zawodowych w zakładowym zabezpieczeniu emerytalnym w Wielkiej Brytanii (stan na 30.03.2015)

Źródło: The Pensions Regulator 2016, s. 25.

Zmieniła się także struktura brytyjskich zakładowych systemów zabezpieczenia emerytalnego, nastąpiło odejście od dominujących wcześniej programów ze zdefiniowanym świadczeniem (defined benefit) w kierunku programów z określoną składką (defined contribution). Jest to rozwiązanie bezpieczniejsze dla pracodaw-

\footnotetext{
2 Najnowsze dane w czasie pisania niniejszego artykułu (styczeń 2017).
} 
cy, gdyż ryzyko inwestycyjne leży po stronie pracownika-uczestnika programu. Pracodawca nie gwarantuje już wypłaty świadczenia z zakładowego systemu emerytalnego w konkretnej, z góry zdefiniowanej wysokości, wynikającej z proporcji do wynagrodzenia, lat pracy itp. (jak w systemie ze zdefiniowanym świadczeniem). Tym niemniej nadzór państwa nad rynkiem emerytalnym oraz silna konkurencja między dostawcami usług finansowych na rynku PPE powodują, że aktywa gromadzone $w$ tych programach przyrastają i nie są narażone na nadmierne ryzyko. Nie oznacza to oczywiście, że takie ryzyko w pełni da się wyeliminować, ponieważ jest ono nierozerwalnie związane $\mathrm{z}$ inwestowaniem na rynku kapitałowym.

$\mathrm{Z}$ analiz przygotowanych na zlecenie rządu brytyjskiego wynika, że jeśli program będzie konsekwentnie wdrażany (a nic nie wskazuje na to, aby miało stać się inaczej, nawet po wyjściu Wielkiej Brytanii z Unii Europejskiej), to w okresie od 2012 do końca 2019 roku można spodziewać się następujących efektów w skali makro:

- 17 mld GBP nowych oszczędności w zakładowych systemach emerytalnych rocznie, z czego 6 mld będą stanowić składki opłacone przez pracodawców, 8 mld - przez pracowników, a 2 mld będzie efektem zastosowania ulg podatkowych dla pracowników (ulgi w podatku dochodowym).

- trzy czwarte wszystkich pracowników kwalifikuje się do auto-enrolment, z czego $63 \%$ stanowią kobiety, a $72 \%$ przedstawiciele mniejszości etnicznych (Departament for Work and Pensions 2016, s. 1).

W Wielkiej Brytanii potwierdziła się prawidłowość zidentyfikowana na gruncie ekonomii behawioralnej. Jedną z barier rozwoju dodatkowych systemów emerytalnych, które wymagają podjęcia świadomej decyzji o włączeniu się do programu emerytalnego, ustaleniu wysokości składki, a często także o wyborze strategii inwestowania, jest zjawisko prokrastynacji (zwlekania, odkładania na później decyzji o oszczędzaniu). Nawet relatywnie wysokie zachęty podatkowe do dodatkowego oszczędzania na emeryturę - w zakładzie pracy lub indywidualnie często są nieskuteczne. Chętniej korzystają z nich osoby o wyższych dochodach i lepiej wykształcone, a nie te, które mają niższe dochody i tym bardziej powinny systematycznie oszczędzać na starość. Zmiana konstrukcji programu wykorzystuje tę niechęć do podjęcia decyzji, swoistą bierność w tej dziedzinie. Jeśli opcją domyślną jest automatyczne włączenie do pracowniczego programu emerytalnego pracowników osiągających określony dochód i nie wymaga to od nich dodatkowej inicjatywy, podczas gdy wyjście z programu (opt-put) wymaga dodatkowego zaangażowania i podjęcia decyzji o długofalowych konsekwencjach finansowych, to większość pracowników pozostaje w programie. Ma tu miejsce tak zwany wybór negatywny. Potwierdza to sensowność wykorzystania dorobku ekonomii behawioralnej w takim konstruowaniu zakładowych systemów emery-talnych czy innych długoterminowych programów oszczędnościowych, która może wykorzystać mechanizm prokrastynacji do pozostania w programie (Benartzi, Thaler 2007; Chłoń-Domińczak, Kawiński i Stańko 2013). 
W okresie wdrażania nowych, quasi-obowiązkowych pracowniczych programów emerytalnych (2012-2015) odnotowano też wiele problemów organizacyjnych, na przykład z rejestracją danych osobowych, komunikacją między pracodawcami a pracownikami, czy prezentacją oferty usług instytucji finansowych obsługujących programy emerytalne, co zresztą jest zjawiskiem naturalnym przy realizacji wszelkiego typu reform społecznych. Nie wchodząc w szczegółowe kwestie organizacyjne czy techniczne, warto zwrócić uwagę na trudności i ograniczenia natury systemowej, prawno-instytucjonalnej i ekonomicznej. Istotnym i nierozwiązanym w pełni problemem jest pozostawienie poza systemem auto-enrolment pracowników o dochodach niższych niż 10 tysięcy GBP rocznie i młodszych niż 22 lata. Osoby te mogą z własnej inicjatywy włączać się do programów zakładowych (opt-in), ale w większości tego nie czynią. Tymczasem są to grupy szczególnie narażone na ubóstwo w wieku starczym. Notabene włączenie najniższych decyli rozkładu dochodów stanowi szerszy problem, występujący nie tylko w Wielkiej Brytanii. Przy niskim dochodzie dyspozycyjnym wyjątkowo trudno jest skłonić pracowników do długoterminowego dodatkowego oszczędzania na emeryturę, nawet przy zastosowaniu relatywnie silnych zachęt fiskalnych (a te akurat w Zjednoczonym Królestwie są umiarkowane). Jak widać na rysunku 1, jedna trzecia ogółu siły roboczej nie była objęta zakładowym zabezpieczeniem emerytalnym. W tej dziedzinie istnieje pole do poprawy, oczywiście biorąc pod uwagę warunki brytyjskie.

$\mathrm{Z}$ badań przeprowadzonych na zlecenie brytyjskiego państwowego regulatora rynku (The Pensions Regulator 2016, s. 16) wynika również, że mimo iż większość automatycznie zapisanych do PPE pracowników pozostawała w zakładowym systemie emerytalnym, wśród tych, którzy z niego występowali (opt-out), najliczniejszą grupę stanowili także pracownicy o najniższych dochodach.

Kolejna zidentyfikowana bariera rozwoju zakładowych systemów emerytalnych w Zjednoczonym Królestwie ma charakter edukacyjny i jest związana z poziomem edukacji emerytalnej, na ogół niższej u pracodawców i pracowników małych firm i mikroprzedsiębiorstw, co potwierdzają wyniki badań opinii publicznej. Pozytywnym zjawiskiem jest jednak wzrost wiedzy na temat systemu auto-enrolment i poziomu świadomości emerytalnej wśród pracodawców i pracowników (również w małych i mikro- firmach), osiągnięty zarówno dzięki prowadzonym przez władze publiczne kampaniom informacyjnym, jak i wymuszony poprzez przepisy prawa - stopniowe włączanie kolejnych grup pracodawców i pracowników do systemu auto-enrolment, konieczność zapewnienia zgodności (compliance) zakładowego systemu płac i rozliczeń finansowych z wymogami prawa w tym zakresie. Można wręcz stwierdzić, że potwierdzona w badaniach ilościowych w 2016 roku znajomość podstawowych założeń auto-enrolement na poziomie blisko $90 \% \mathrm{w}$ grupie pracodawców w zakładach pracy zatrudniających od 5 do 50 osób i około $75 \%$ w mikrofirmach zatrudniających do 4 pracowników była bardzo wysoka, wręcz imponująca (Employers reserach 2016). 
Ciekawych danych na temat pracowników automatycznie zapisanych do programu, którzy w ciągu pierwszego miesiąca z niego wystąpili (opt-out) i wypłacili swoje składki odprowadzone do programu, dostarcza badanie przeprowadzone w 2013 roku na próbie reprezentatywnej 3 tysiący pracodawców (Automatic Enrolment 2013). Jego uzupełnieniem było badanie jakościowe w przedsiębiorstwach włączanych do quasi-obowiązkowego systemu zakładowego zabezpieczenia emerytalnego w roku 2014 (Automatic Enrolment 2014). Z obu sondaży wynika, że procentowy udział pracowników, którzy wybrali opcję wyjścia z pracowniczego programu emerytalnego, do którego zostali automatycznie włączeni, był stosunkowo niewielki - w latach 2012-2014 kształtował się w przedziale 9-10\%. Było to mniej, niż założono na etapie uruchamiania programu w 2012 roku, kiedy przyjmowano, że z rozwiązania opt-out skorzysta do 30\% pracowników. W relatywnie nielicznej grupie osób występujących z PPE w ciągu pierwszego miesiąca od zapisu dominowały, jak można było przewidzieć, osoby o najniższych dochodach. Jednakże patrząc z innej perspektywy, niewątpliwie za duży sukces wprowadzenia quasi-obowiązkowego uczestnictwa w zakładowych systemach emerytalnych w Wielkiej Brytanii należy uznać fakt, że z uprawnionych do uczestnictwa osób z najniższych decyli dochodowych (zbliżonych do rocznego dochodu 10 tysięcy GBP) około $90 \%$ pozostało w programie i opłacało składki do PPE. Z osób o jeszcze niższych dochodach, które mogły dobrowolnie zadeklarować udział $\mathrm{w}$ systemie zakładowym, zdecydowało się na to niewiele osób z próby badawczej — około 1\% (The Pensions Regulator 2014, s. 30).

\section{Wnioski}

Na podstawie przeprowadzonych badań można udzielić odpowiedzi na postawione we wstępie pytania badawcze. Bez wątpienia automatic enrolment, czyli automatyczne zapisywanie nowo przyjętych pracowników do pracowniczego programu emerytalnego (z możliwością odstąpienia i wycofania wpłaconej składki w określonym, stosunkowo krótkim czasie), przyczyniło się do zwiększenia poziomu uczestnictwa w zakładowym zabezpieczeniu emerytalnym oraz do wygenerowania nowych, dodatkowych, znaczących oszczędności emerytalnych w Wielkiej Brytanii. Program spełnił zatem pokładane w nim nadzieje mimo pojawiających się u niektórych pracodawców problemów w jego implementacji. Potwierdziła się zbadana i opisana na gruncie ekonomii behawioralnej prawidłowość, zgodnie z którą, jeśli opcją domyślną jest włączenie do programu, a wyjście z PPE wymaga czynnego zaangażowania, to większość osób będzie odwlekać podjęcie decyzji (prokrastynacja). Dodatkowym bodźcem do pozostania w programie jest zaangażowanie państwa (ulga podatkowa) oraz pracodawcy, który dopłaca swoją część składki do programu. 
Doświadczenia brytyjskie (a także innych krajów, które wprowadziły automatic enrolment) są zachęcające dla innych państw Unii Europejskiej ze względu na poszerzenie zakresu uczestnictwa w PPE o grupy pracownicze o niższych dochodach, czego zwykle nie udaje się osiągnąć przy dobrowolnym uczestnictwie, gdyż z ulg podatkowych czy innych zachęt ekonomicznych najchętniej korzystają grupy pracowników o wyższych dochodach. Zagrożeniem jest jednak to, że mimo wszystko część pracowników o niskim dochodzie uzyskiwanym dzięki pracy, a co za tym idzie - niskim dochodzie dyspozycyjnym, niestety rezygnuje z dodatkowego oszczędzania na emeryturę w zakładzie pracy. Zwiększanie zachęt fiskalnych kierowanych do uczestników PPE nie rozwiąże tego problemu, poza tym - jak już wspomniano - najczęściej korzystają z nich pracownicy z górnych przedziałów rozkładu dochodów z pracy. Przy założeniu, że dodatkowe oszczędzanie na starość w zakładowych systemach emerytalnych jest niezbędne, alternatywą dla automatycznego zapisu z opcją wyjścia (quasi-obowiązkowe uczestnictwo) może być — jak można przypuszczać — jedynie uczestnictwo obligatoryjne. To ostatnie rozwiązanie nie wymaga dodatkowych zachęt podatkowych, ale z różnych względów (także z uwagi na przyjętą doktrynę polityki społecznej i tradycję instytucjonalną) nie w każdym kraju może zostać zastosowane. Wprowadzanie quasi-obowiązkowego uczestnictwa w PPE wymaga wypracowania konsensusu wśród różnych grup interesariuszy (zwłaszcza pracodawców i pracowników), a także szeroko zakrojonej akcji informacyjnej. W Wielkiej Brytanii oba te warunki zostały spełnione. Dlatego już po czterech latach wdrażania programu (faza implementacji ma potrwać sześć lat) można stwierdzić, iż okazał się on skuteczny i przyczynił się do zwiększenia poziomu zabezpieczenia emerytalnego.

Rozważając wprowadzenie również w Polsce kolejnej reformy emerytalnej, zmierzającej do upowszechnienia zakładowego zabezpieczenia emerytalnego, warto niewątpliwie wykorzystać doświadczenia brytyjskie.

\section{Bibliografia}

Amzallag A., Kapp D. \& Kok Ch. (2014), The impact of regulating occupational pensions in Europe on investment and financial stability. Occasional Paper Series, „European Central Bank” 145, July, https://www.ecb.europa.eu/pub/pdf/scpops/ecbop154.pdf?402378bdd94da2a82b4113a9b 4eb8bd7 (dostęp: 16.01.2017).

Automatic Enrolment (2013), Qualitative research with large employers, http://bit.ly/QRlarge (dostęp: 15.01.2017).

Automatic Enrolment (2014), Qualitative research with employers staging in 2014, http://bit.ly/ QRstage14 (dostęp: 16.01.2017).

Barr N., Diamond P. (2010), Pension Reform. A Short Guide, New York.

Benartzi S., Thaler R. (2007), Heuristics and biases of Retirement Savings, „The Journal of Economic Perspectives" 21, nr 3, s. 81-104. 
Better Finance (2016), Pension Savings. The Real Return. A Research Report by BETTER FINANCE, Brussels, http://betterfinance.eu/fileadmin/user_upload/documents/Research_Reports/en/Pension_report_2016_For_Web_-_Final.pdf (dostęp: 10.01.2017).

Blake D. (2006), Pension Economics, Pensions Institute, Chichester.

Chłoń-Domińczak A., Kawiński M. i Stańko D. (2013), System oceny i prezentacji wyników inwestycyjnych kapitałowych systemów emerytalnych, Warszawa.

Chybalski F. (red.) (2016), Adekwatność dochodowa, efektywność i redystrybucja w systemach emerytalnych, Warszawa.

Department for Work and Pensions (2016), Workplace pensions: Update of analysis on Automatic Enrolment 2016, https://www.gov.uk/government/uploads/system/uploads/attachment data/ file/560356/workplace-pensions-update-analysis-auto-enrolment-2016.pdf(dostęp: 10.01.2017).

Employers research (2016), Survey, 15 grudnia, http://www.thepensionsregulator.gov.uk/research \#s16192.

OECD (2005), Private Pensions. OECD Classification and Glossary, Paris, http://www.oecd.org/finance/privatepensions/privatepensionsoecdclassificationandglossary.htm (dostęp: 5.01.2017).

OECD (2015), Pensions at a Glance 2015: OECD and G20 indicators, Paris, http://dx.doi.org/10.1787/ pension_glance-2015-en (dostęp: 15.12.2016).

OECD (2016), OECD Pensions Outlook 2016, Paris, http://dx.doi.org/10.1787/pens_outlook-2016en (dostęp: 15.12.2016).

Petelczyc J. (2016), Pracownicze programy emerytalne w krajach Unii Europejskiej, Warszawa.

The Pensions Advisory Service (2016), Automatic Enrolment, 18 grudnia, http://www.pensionsadvisoryservice.org.uk/about-pensions/pensions-basics (dostęp: 15.01.2017).

The Pensions Regulator (2014), Automatic enrolment. Commentary and analysis: April 2014-March 2015, https://www.gov.uk (dostęp: 15.01.2017).

The Pensions Regulator (2016), Automatic enrolment. Commentary and analysis: April 2015-March 2016, 18 grudnia, https:/www.gov.uk.

Towers W. (2016), Automatic Enrollment in UK, https://www.towerswatsoncom (dostęp: 18.01.2017).

Żukowski M. (1997), Wielostopniowe systemy zabezpieczenia emerytalnego w Unii Europejskiej $i$ w Polsce. Między państwem a rynkiem, Poznań.

Ekonomia - Wroclaw Economic Review 23/3 (2017)

(C) for this edition by CNS 